\title{
Role of the vitamin $C$ in diethylnitrosamine-induced esophageal cancer in Wistar rats $^{1}$
}

\author{
O efeito inibidor da vitamina $\mathrm{C}$ na carcinogênese esofágica induzida pela dietilnitrosamina em \\ ratos Wistar
}

\author{
Almino Cardoso Ramos', Marina Rachel Araujo ${ }^{\text {II }}$, Luiz Roberto Lopes ${ }^{\text {III }}$, Nelson Adami Andreollo ${ }^{\text {IV }}$

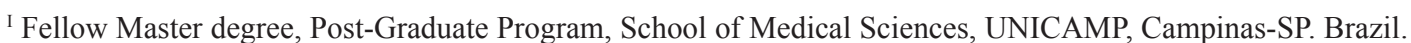

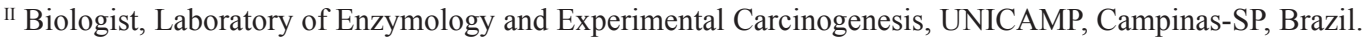 \\ III Associate Professor, Digestive Disease Division, Department of Surgery, UNICAMP, Campinas-SP, Brazil. \\ ${ }^{\text {IV }}$ Full Professor, Digestive Disease Division, Department of Surgery, UNICAMP, Campinas-SP, Brazil.
}

\begin{abstract}
Purpose: To evaluate the inhibitory effect of vitamin $\mathrm{C}$ on the experimental esophageal carcinogenesis induced by diethylnitrosamine (NDEA). Methods: Sixty Wistar male rats aged three months, with mean weight of $210 \mathrm{~g}$ were employed in the study and were divided into four different groups according to the drinking drugs: group I - controls: only water, seven days a week; group II - only vitamin C, seven days a week; group III - NDEA, three days a week and water during the other four days; group IV - NDEA, three days a week and vitamin $\mathrm{C}$ during the other four days; group V - NDEA together with vitamin $\mathrm{C}$ three days a week, and only water during the other four days and group VI - NDEA together with vitamin $\mathrm{C}$ three days a week and vitamin $\mathrm{C}$ during the other four days. The dosages of NDEA were: - $10 \mathrm{mg}$. / Kg / day and vitamin C $-200 \mathrm{mg}$ / animal / day, dissolved in drinking water. The animals were observed during 180 days and after that each one was sacrificed and its esophagus and the stomach were removed together and macro and microscopically analyzed to identify any tumors. Results: The largest number of tumors was observed in the group III: 48 macroscopic lesions (4.8 lesions per animal) and 23 microscopic lesions (2.3 lesions per animal). The groups that received vitamin C (groups IV, V and VI) showed smaller number of tumors: group V -0.5 macroscopic lesions and 0.3 microscopic lesions per animal and group VI - 0.1 macroscopic lesions and 0.1 microscopic lesions per animal. The incidence of tumors in the groups $\mathrm{V}$ and VI showed statistical significance $(\mathrm{p}<0.05)$, when compared to the other groups. Conclusion: The vitamin $\mathrm{C}$ administered together with diethylnitrosamine showed an inhibitory effect on the experimental esophageal carcinogenesis in Wistar rats.
\end{abstract}

Key words: Esophageal Neoplasms. Diethylnitrosamine. Ascorbic Acid. Rats.

\section{RESUMO}

Objetivo: Avaliar o efeito inibidor da vitamina C na carcinogênese esofágica experimental induzida pela dietilnitrosamina (DEN). Métodos: Sessenta ratos Wistar, com idade de três meses, machos, com peso médio de $210 \mathrm{~g}$ foram utilizados no estudo e divididos em quatro grupos diferentes, conforme ingestão das drogas: grupo I - controles: ingerindo água sete dias por semana; grupo II - só vitamina C, sete dias por semana; grupo III - DEN, três dias por semana e água durante os outros quatro dias; grupo IV - DEN, três dias por semana e vitamina $\mathrm{C}$ durante os outros quatro dias; grupo $\mathrm{V}$ - DEN junto com vitamina $\mathrm{C}$ três dias por semana, e água os outros quatro dias e grupo VI - DEN junto com vitamina $\mathrm{C}$ três dias por semana e só vitamina $\mathrm{C}$ durante os outros quatro dias. As dosagens de DEN empregadas foram - $10 \mathrm{mg}$. / Kg / dia e de vitamina C - $200 \mathrm{mg}$ / animal / dia, dissolvidos na água de beber. Os animais foram observados durante 180 dias e depois disso sacrificados, tiveram o seu esôfago e o estômago retirados, e macro e microscòpicamente analisados para identificar qualquer tumor. Resultados: O número maior de tumores foi observado no grupo III: 48 lesões macroscópicas (4.8 lesões por animal) e 23 lesões microscópicas (2.3 lesões por animal). Os grupos que receberam vitamina C (grupos IV, V e VI) evidenciaram número menor de tumores: grupo V - 0.5 lesões macroscópicas e 0.3 lesões microscópicas por animal e grupo VI - 0.1 lesões macroscópicas e 0.1 lesões microscópicas por animal. A incidência de tumores nos grupos V e VI mostraram diferença estatística significa ( $p<0.05$ ), quando comparados aos outros grupos. Conclusão: A vitamina $\mathrm{C}$ administrada junto com dietilnitrosamina mostrou efeito inibidor no aparecimento de tumores esofágicos.

Descritores: Neoplasias Esofágicas. Dietilnitrosamina. Ácido Ascórbico. Ratos.

${ }^{1}$ Research performed at the Laboratory of Enzymology and Experimental Carcinogenesis, School of Medical Sciences, Campinas University (UNICAMP), Sao Paulo, Brazil. 


\section{Introduction}

Esophageal cancer is among the ten more frequent types of malignant tumours of the world, representing approximately $1 \%$ of all of the lesions. It constitutes the fourth neoplasia that influence the man's digestive system, and its studies are very important, basically for two reasons: first, this type of cancer affects people in their most natural life proceeding: nutrition; second, its occurrence rates are quite similar to those of mortality, clearly demonstrating the treatment inefficacy. However, two procedures may change this terrifying picture: early diagnosis and prevention. Therefore, the search for substances that may interfere with the carcinogenesis keeping away the possibilities of new tumors, is a very attractive idea $^{1,2}$. Recent studies demonstrated that the consumption of fruits and vegetables rich in vitamin $\mathrm{C}$ is inversely related to the indexes of esophageal, stomach, oral cavity and pancreatic cancers. Vitamin $\mathrm{C}$ seems to influence considerably less the uterus, rectum, mamma and lung. The mechanism by which the vitamin $C$ has protective action on the carcinogenesis is controversial and several hypotheses are arisen ${ }^{3,4}$.

Diethylnitrosamine (NDEA) it is a well known N-nitrous compound that provokes esophageal cancer, and a lot of defined models can be used for the disease induction in laboratory animals ${ }^{5,6}$. Several researches carried out during the last years have made efforts to find a substance to eliminate the nitrosamine noxious effects, once the exogenous and endogenous contact with this compound is extremely common every day. Studies showed that the vitamin $\mathrm{C}$ is capable to prevent nitrosation, and to interfere with experimentally induced carcinogenesis ${ }^{3,4}$.

The objective of this study was to evaluate by macroscopic and microscopic analysis the inhibitory effect of the vitamin $\mathrm{C}$ on experimental NDEA-induced esophageal carcinogenesis in rats.

\section{Methods}

The experimental protocol was previously approved by the Ethics Committee for Animal Experimentation of the State University of Campinas - Unicamp. Sample size was calculated for a standard deviation of $10 \%$, difference between proportions of $5 \%$ and significance of 0.05 .

The sixty Wistar male rats (SPF - specific pathogen free) used in this study, were supplied by the Animal Reproductive Center of the State University of Campinas. They were under ideal conditions of health and feeding, aging three months and weighting between 150 and $220 \mathrm{~g}($ mean $=210 \mathrm{~g})$.

Diethylnitrosamine (NDEA) was acquired from the Sigma (Sigma Chemicals Co. St. Louis, Millstone - USA), flask with $100 \mathrm{ml}$, density of $0.95 \mathrm{~g} / \mathrm{ml}$, molecular weight of $102.1 \mathrm{~g} / \mathrm{mol}$ and chemical formula $\mathrm{C} 4 \mathrm{H} 10 \mathrm{~N} 2 \mathrm{O}$. The compound was diluted in drinking water, and administered to the animals for 3 days of the week, in the dosage of $10 \mathrm{mg} / \mathrm{Kg}$ of corporal weight, based on a mean consumption of water of $40 \mathrm{ml}$ per animal.

Vitamin C, it was obtained from EMS - Pharmaceutical Industry, Campinas, São Paulo, Brazil (flask of $5 \mathrm{ml} / 500 \mathrm{mg}$ ), and prepared fresh in drinking water at intervals throughout the study and administered to the animals in a dosage of $200 \mathrm{mg} / \mathrm{animal} /$ day.

The animals were divided into six groups (I, II, III, IV, V, VI) with ten rats, which received water, vitamin $\mathrm{C}$ and NDEA in alternate days (Table 1), and observed for 180 days. Afterwards, they were sacrificed and submitted to the necropsy soon after the death. The esophagus was removed and opened to be macro and microscopically analyzed and classified according to the Japanese School standartization ${ }^{7}$. The pieces were extended on polystyrene plaques and secured with pins and then transversally cut, obtaining fragments of about $2 \mathrm{~mm}$. All the fragments were identified, placed in vessels with $10 \%$ formaldehyde solution and processed by the usual methods to obtain histological cuts, which were stained by hematoxylin and eosin.

TABLE 1 - Groups of animals and drugs used

\begin{tabular}{c|l}
\hline GROUPS & \multicolumn{1}{|c}{ DRUGS } \\
II & Vontrols - only water. \\
III & NDEA 3 days of the week. \\
IV & NDEA 3 days of the week, alternated with vitamin C during the other 4 days. \\
v & NDEA and vitamin C together for 3 days of the week and water during the other 4 days. \\
VI & NDEA and vitamin C together for 3 days of the week and only vitamin C during the other 4 days \\
\hline
\end{tabular}


The Kruskal Wallis Test (nonparametric variance analysis) was used for the statistical analysis followed by multiple comparisons using the DUNN Test for number of tumors and the Fischer's Exact Test for comparison of proportions, with significance of $5 \%(\mathrm{p}<0.05)$.

\section{Results}

None rat in the groups that did not receive NDEA presented tumor (I and II), on the other hand, all of the groups that received NDEA (III, IV, V, VI) presented tumors. Squamous cell carcinomas were found in all macroscopic tumors. The largest number of neoplastic lesions was observed in the group III. In this group 48 macroscopic lesions (4.8 lesions per animal) and $23 \mathrm{mi}-$ croscopic lesions (2.3 lesions per animal) were found. The group IV presented 31 macroscopic lesions (3.1 lesions per animal) and 17 microscopic lesions (1.7 lesions per animal) (Figures 1 and 2). There was no statistical significance $(p<0.05)$ between the groups III and IV as for the number of tumors observed.

A smaller number of tumors was found in the groups IV, $\mathrm{V}$ and VI, which received Vitamin $\mathrm{C}$ : group V -0.5 macroscopic lesion for animal and 0.3 microscopic lesion for animal and group VI - 0.1 macroscopic lesions per animal and 0.1 microscopic lesions per animal (Figure 2). It was verified statistical significance $(p<0.05)$ as for the reduction in the incidence of tumors in the groups V and VI, when compared to the other groups.

Therefore, an important inhibitory effect of the vitamin C on esophageal carcinogenesis occurred in the groups V and VI.

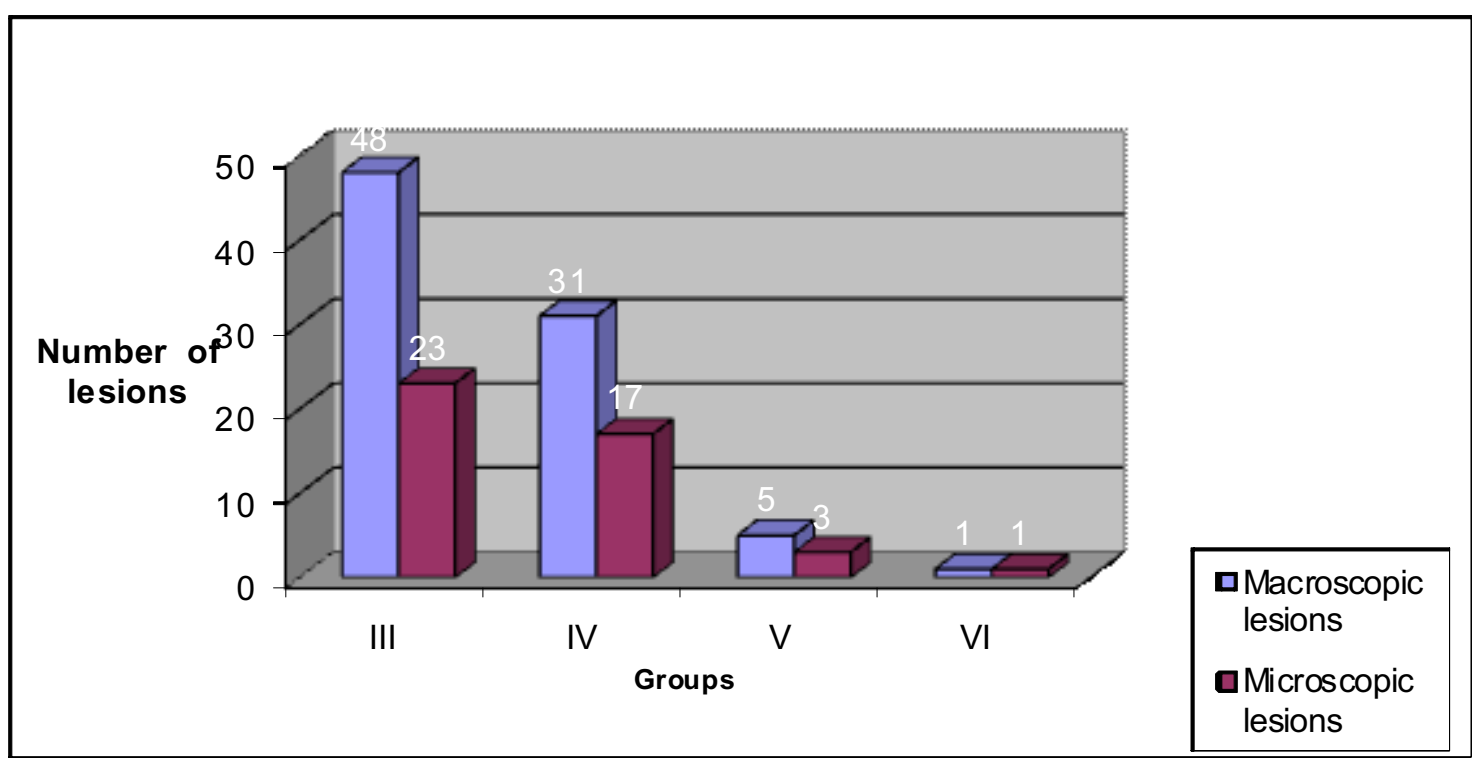

FIGURE 1 - Number of lesions in the groups

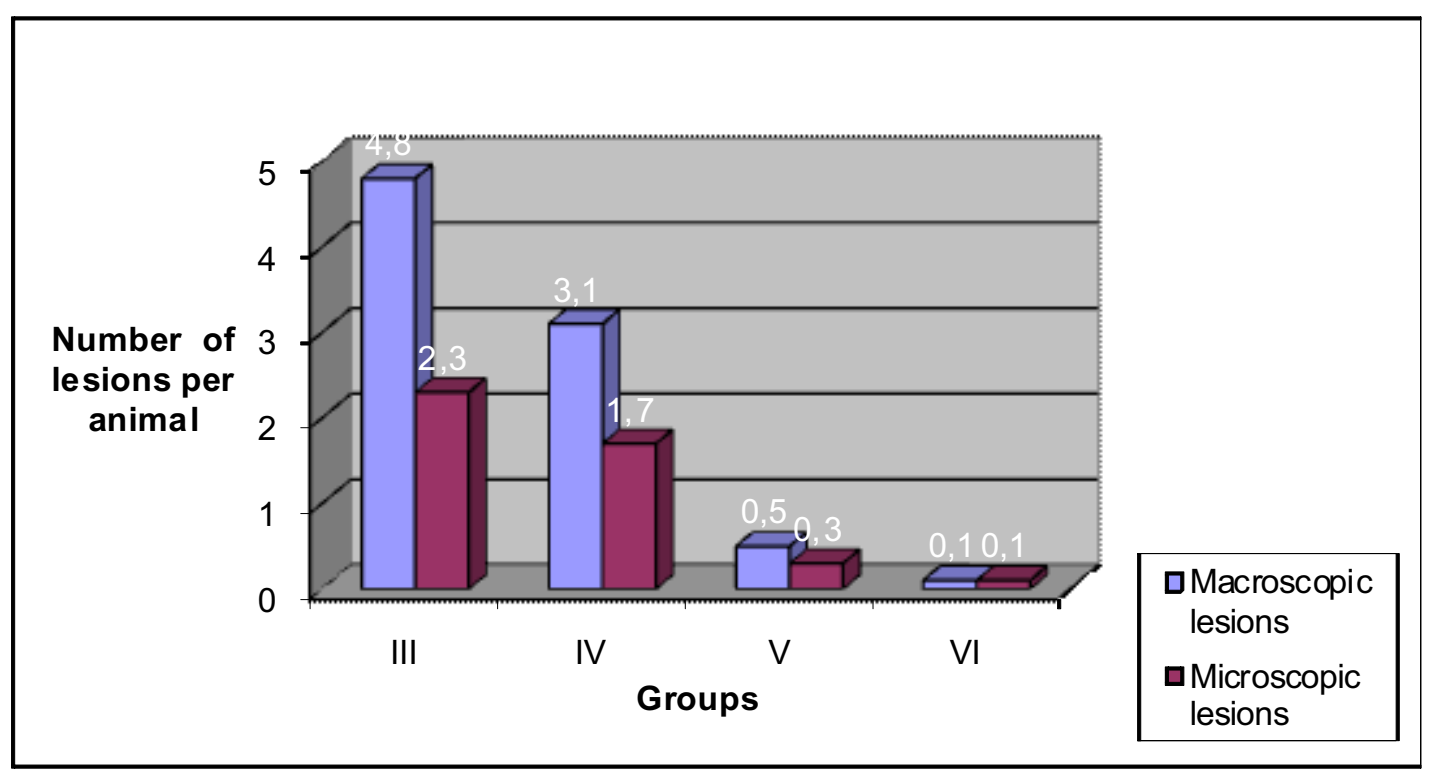

FIGURE 2 - Number of lesions per animal 


\section{Discussion}

Squamous cell carcinoma (SCC) and the adenocarcinoma are the main esophageal tumors, both with different etiologies. The SCC represents $90 \%$ of the prevalence of esophageal cancer in the world ${ }^{8,9}$.

Tabagism is considered as main factor in the etiology of esophageal SCC. Researches already demonstrated that the nitrosamines present in the tobacco are related to the esophageal cancer. The consumption of alcohol and salty foods, as well as deficiencies of vitamins and some minerals are responsible for the occurrence of the same tumor. In areas of high risk for this disease, low plasmatic levels of vitamins $\mathrm{A}, \mathrm{C}$, and $\mathrm{E}$ as well as selenium, zinc and other elements in the diet are inversely related to the mortality rate for esophageal cancer ${ }^{10,11}$.

Nitrosamines, which are considered N-nitrous compounds, are employed by many researchers as chemical inductors of tumors. They cause DNA lesions and in consequence cancer. In addition, they are associated with carcinogenesis in at least 40 animal species including primates, and the induced neoplastic cellular alterations are similar to those found in human tissues ${ }^{12}$.

The exhibition to N-nitrous compounds can occur directly through preformed products (tobacco, occupational exhibitions and diet) compound that contains nitrosating agents, which reacted to form nitrosamines and endogenous synthesis of nitrates, nitrites and nitrosating agents in reactions mediated by bacteria and the macrophages $^{13}$.

The understanding of the carcinogenesis is fundamental for the creation of efficient mechanisms for appropriate approach of the cancer, its treatment and prevention. There are three mechanisms for prevention of carcinogenesis caused by nitrosamines: avoid contact with preformed nitrosamines, protect against endogenous nitrosation and biochemical blockade from the action of the nitrosamines ${ }^{14}$

Epidemiological studies suggest an inverse relationship between the consumption of fruits and vegetables and the occurrence of some types of cancer, including the esophagus cancer. It means that a diet deficient in fresh fruits and vegetables is associated of increased risk for some cancers. It is believed that there is an abundance of natural preventive agents found in fruits and vegetables, including vitamins and minerals ${ }^{10}$.

Carlton et al. ${ }^{15}$, using a diet based on frozen fresh strawberries, they observed the capacity to inhibit carcinogenesis in esophagus of mice. It is a fruit rich in ellagic acid, a compound associated with inhibition of the metabolism of $\mathrm{N}$ nitrosomethylbenzylamine (NMBA) in cultures of esophagus of mice and NMBA-induced carcinogenesis used in experimental studies. This diet was administered to rats during 30 weeks and two weeks after the NMBA was administered, as an experimental model of carcinogenesis induced in small animals. In spite of not demonstrating significant difference in the incidence of tumors, it showed a significant reduction of $24 \%$ in the multiplicity of tumors, in a dependent way to the dosage - 4.1 to 3.1 lesions per animal $(\mathrm{p}<0.05)$, and $56 \%-4.1$ to 1.8 lesions for animal $(\mathrm{p}<0.05)$ in comparison to rats that only received NMBA. In addition, the diet administered before, during and after the treatment with NMBA, modulated the development of preneoplastic lesions and reduced the multiplicity of esophageal tumors in rats, in a dependent way to the dosage ${ }^{16}$.
Carlton et al. $^{15}$ also observed other compounds in high relative concentrations in the diet of frozen dry strawberries, including the vitamin $\mathrm{C}$ (1.41 and $2.98 \mathrm{mg} / \mathrm{g}$ dry weight) and calcium (1.6 and $1.74 \mathrm{mg} / \mathrm{g}$ dry weight).

Studies demonstrated that the ingestion of vitamin $\mathrm{C}$ in fruits and vegetables is inversely related to the indexes of stomach cancer, esophageal, oral cavity and pancreatic cancer ${ }^{3}$. The opinion that there are mechanisms by which the vitamin $\mathrm{C}$ may act by protecting against carcinogenesis is controversial, and several hypotheses are rised.

The correlation between cancer and ascorbic acid has been discussed nowadays, although it is not a recent theme. Eufinger and Gaehtgens ${ }^{17}$, in 1936, reported the successful treatment of myeloid leukemia using vitamin $\mathrm{C}$, and ever since, it is has been receiving attention as substance capable of acting in carcinogenesis prevention. Several epidemiological studies had been performed trying to relate cancer and vitamin $\mathrm{C}$ consumption, in the normal diets or as alimentary supplement.

The Committee on Diet, Nutrition and Cancer of the National Academy of Sciences showed in 1982, that the vitamin C inhibits the formation of some carcinogens and that the consumption of foods rich in vitamin $\mathrm{C}$ would be associated with low risk for esophageal and stomach carcinomas ${ }^{4}$.

Diethylnitrosamine (NDEA), a substance known for more than 30 years due to its capacity of formation of tumors, was used in this study for induction of esophageal cancer ${ }^{18}$, following the Rubio standardization ${ }^{19}$ and Sallet et al. researches ${ }^{5,6}$.

The main mechanism by which the vitamin $\mathrm{C}$ may interfere with carcinogenesis is related to its ability in reducing the nitrous acid, preventing the formation of nitrosamines in the stomach $^{17}$.

Based on measures of the ascorbic acid in the gastric juice and gastric $\mathrm{pH}$, Schorah et al. ${ }^{20}$, observed that the nitrosation depends on the gastric acid secretion, of the $\mathrm{pH}$ and the bacterial synthesis at high $\mathrm{pH}$. They demonstrated that the $300 \mathrm{~mol} / \mathrm{L}$ is the ideal concentration of ascorbic acid to inhibit nitrosation, which occurs in humans with a daily oral ingestion of $200 \mathrm{mg}$ of vitamin C.

Ausman $^{21}$ advised a daily consumption of $70-80 \mathrm{mg} /$ day of vitamin $\mathrm{C}$ for the USA population, an amount well below the five portions of fruits and vegetables a day, which would totalize 200-280 mg/day of vitamin C, recommended by the United States Department of Agriculture and for the National Institute of Cancer.

The recommendation of vitamin $\mathrm{C}$ consumption for adults is of $60 \mathrm{mg} / \mathrm{day}^{21}$. Authors, such Rumsey and Daruwala ${ }^{22}$, suggest a daily ingestion of 100-120 mg/day, through the daily consumption of 5 portions of fruits and vegetables, and a maximum of $1,0 \mathrm{~g} /$ day, as a safe measure to avoid adverse effects of excessive ingestion.

Although the esophageal carcinogenesis has multiple stages, the $\mathrm{p} 53$ protein mutation seems to happen early, preceding the phenotype alteration. The action in vitro of the ascorbic acid was evaluated on normal cells and tumor cells of the pancreas, larynx and uterus, demonstrating an effect related to vitamin $\mathrm{C}$ concentration on induced-apoptose of neoplastic cells, supporting the hypothesis of vitamin $\mathrm{C}$ effect on the genes c-myc and p53. Another mechanism of action of the vitamin $\mathrm{C}$ would be related to the blockade or competition with carcinogens for cytochrome P450 
enzymes, blocking its metabolic activation ${ }^{21,22,23,24}$.

Free radicals can react in carcinogenesis, causing DNA oxidative lesions or cell wall damage, facilitating the entrance and action of carcinogens, such as the nitrosamines, which are very important in the formation of tumors. In sperm studies it was already demonstrated the capacity of the vitamin $\mathrm{C}$ for protecting DNA from oxidative lesions. Considering that vitamin $\mathrm{C}$ is an antioxidant, it would act by supplying electrons for neutralization of the free radicals $\mathrm{s}^{25,26,27,28}$.

Oliveira et al. ${ }^{29}$ studied the antioxidant effects vitamin C in experimental gastric cancer model induced in Wistar rats $(30 \mathrm{mg} / \mathrm{Kg} /$ day) and they found reduction of oxidative stress and gastric tumor incidence. They concluded that vitamin $\mathrm{C}$ may have a role in prevention of gastric carcinoma.

Sasazuki et al. ${ }^{31}$ verify effect of 5 -year vitamin C supplementation on serum pepsinogen level and Helicobacter pylori infection and conclude that the vitamin $\mathrm{C}$ supplementation may protect against progression of gastric mucosal atrophy ${ }^{30}$. Telang et al..$^{31}$ demonstrated in an experimental model using rats that the vitamin $\mathrm{C}$ has an important angiogenic action, delaying the tumoral growth.

The multiplicity of the neoplastic lesions found in this research varied from 2.3 to 0.3 lesions per animal (groups III and $\mathrm{V}$ respectively) and of 2.3 for 0.1 lesions per animal (groups III and VI, respectively), also with statistical difference. The results showed reduction of macroscopic and microscopic lesions of 35\% $(p<0.01)$ and $26 \%(p<0.01)$ respectively in the Group IV, compared to the group III; however without statistical significance. On the other hand, a significant reduction of lesions was recorded in the groups V and VI, with statistical difference. Comparing the groups III and V, there was a reduction of $89 \%$ (48 for 5 macroscopic lesions) and $87 \%$ (23 for 3 microscopic lesions), $\mathrm{p}<001$; and comparing the groups III and VI it was observed a reduction of 98\% (48 for 1 macroscopic lesion) and 95\% (23 for 1 microscopic lesion), $\mathrm{p}<0.01$. Therefore, the vitamin $\mathrm{C}$ decreased the number of esophageal tumors.

The literature revised did not demonstrate the possibility that when the vitamin $C$ was mixed with the NDEA solution, the vitamin $\mathrm{C}$ decomposed the NDEA. The data obtained by the present study are in accordance with the theory that the vitamin $\mathrm{C}$ inhibits strongly the esophageal carcinogenesis (Figure 2) ) $^{18,22,28}$. Studies demonstrated the direct effect vitamin $\mathrm{C}$ on carcinogen blockade, such as the conversion of the benzopyrene and anthracene to less poisonous substances ${ }^{27}$, the inactivation of organochlorine pesti$\mathrm{cides}^{27}$, and the prevention of the oxidative lesions from ozone and hydrogen oxide in association which vitamin $\mathrm{D}^{28}$.

In spite of being consistent and exciting, some aspects should be considered. First, the data are related to the effect of the vitamin $\mathrm{C}$ on NDEA-induced esophageal carcinogenesis induced by in Wistar rats. Any extrapolation for esophageal carcinogenesis in general and in humans it should be done with caution. Second, the vitamin $\mathrm{C}$ dosage that the animals received, would correspond to the about $90 \mathrm{~g} /$ day for an individual of $70 \mathrm{Kg}$, being difficult its usage in the general population. Certainly, others researches needs to be developed, and a new door is open for carcinogenesis research.

\section{Conclusion}

The vitamin $\mathrm{C}$ administered together with diethylnitrosamine showed an inhibitory effect on the experimental esophageal carcinogenesis in Wistar rats.

\section{References}

1. Holmes RS, Vaughan TL. Epidemiology and pathogenesis of esophageal cancer. Semin Radiat Oncol. 2007;17(1):2-9.

2. Ribeiro Pinto LF, Teixeira Rossini AM, Albano RM, Felzenszwalb I, de Moura Gallo CV, Nunes RA, Andreollo NA Mechanisms of esophageal cancer development in Brazilians. Mutat Res. 2003;544(2-3):365-73.

3. Block, G. Epidemiologic evidence regarding vitamin $\mathrm{C}$ and cancer. Am J Clin Nutr. 1991;54(6 Suppl):1310S-4S.

4. Bollschweiler E, Wolfgarten E, Nowroth T, Rosendahl U, Monig SP, Holscher AH. Vitamin intake and risk of subtypes of esophageal cancer in Germany. J Cancer Res Clin Oncol. 2002;128(10):575-80.

5. Sallet JA, Andreollo NA, Venco F, Brandalise NA, Leonardi LS. The epidermoid carcinoma of the esophagus induced by diethylnitrosamine (den). Acta Cir Bras. 1996;11(3):138-43.

6. Sallet JA, Zilberstein B, Andreollo NA, Eshkenazy R, Pajecki D. Experimental esophageal carcinogenesis: technical standardization and results. Dis Esophagus. 2002;15(4):278-81.

7. Japanese Society for Esophageal Diseases. Guide lines for the clinical and pathologic studies on carcinoma of the esophagus. Jpn J Surg. 1976;6(2):69-78.

8. Stoner G, Gupta A. Etiology and chemoprevention of esophageal squamous cell carcinoma. Carcinogenesis. 2001;22(11):1737-46.

9. Stoner GD, Rustgi AK. Biology of esophageal squamous cell carcinoma. Gastrointest Cancers Biol Diagn Ther. 1995;8:141-6.

10. Ribeiro JR U, Posner M, Safatle-Ribeiro A, Reynolds J. Risk factors for squamous cell carcinoma of the oesophagus. Br J Surg. 1996;83(9):1174-85.

11. Charalabopoulos K, Karkabounas S, Dimicco P, Binolis J, Charalabopoulos A, Zelovitis J, Avdikos A, Metsios A, Peschos D, Agnantis NJ, Evangelou A. The role of ascorbic acid, selenium, and glutathione on benzo[a]pyrene-induced carcinogenesis in wistar rats. J Buon. 2004;9(2):187-92.

12. Bartsch H. N-nitroso compounds and human cancer: where do we stand? IARC Sci Publ. 1991;105:1-10.

13. Eichholzer M, Gutzwiller F. Dietary nitrates, nitrites, and N-nitroso compounds and cancer risk: a review of the epidemiologic evidence. Nutr Rev. 1998;56(4 Pt 1):95-105.

14. Hecht SS. Approaches to cancer prevention based on an understanding of N-nitrosamine carcinogenesis. Proc Soc Exp Biol Med. 1997;216(2):181-91.

15. Carlton PS, Kresty LA, Siglin JC, Morse MA, Lu J, Morgan C, Stoner GD. Inhibition of N-nitrosomethylbenzylamine-induced tumorigenesis in the rat esophagus by dietary freeze dried strawberries. Carcinogenesis. 2001;22(3):441-6.

16. Mandal S, Shivapurkar NM, Galati AJ, Stoner GD. Inhibition of ellagic acid in various fruits and nuts. J Food Comp Anal. 1998;2:338-49.

17. Eufinger H, Gaehtgens G. Ueber die Einwirkung des Vitamin C auf das pathologisch veranderte weisse Blutbild Klin Wochenschr. 1936;15:150-6.

18. Fransson LA, Mani K. Novel aspects of vitamin C: how important is glypican-1 recycling? Trends Mol Med. 2007;13(4):143-9.

19. Rubio CA. Epitelial lesions antedating oesophageal carcinoma. Histologic study in mice. Pathol Res Pract. 1983;176:269-75.

20. Schorah CJ, Sobala GM, Sanderson M. Gastric juice ascorbic acid: effects of disease and implications for gastric carcinogenesis. Am J Clin Nutr. 1991;53:287-93. 
21. Ausman, LM, Criteria and recommendations for vitamin C intake. Nutr Rev. 1999;57(7):222-4.

22. Rumsey SC, Daruwala R. Criteria and recommendations for Vitamin C intake. JAMA 1999; 281:14-23.

23. Wang LD, Hong JY, Qui, S. Accumulation of p53 protein in human esophageal precancerous lesions: a possible early biomarker for carcinogenesis. Cancer Res. 1993;53:1783-7.

24. Sarbia M, Porschen R, Borchard F. p53 protein expression and prognosis in squamous cell carcinoma of the esophagus. Cancer. 1994; 74:2218-23.

25. Gridisa M, Kralj M, Ackert-Maksic M. 6-amino-deoxyascorbic acid induces apoptosis in human tumor cells. J Cancer Res Clin Oncol. 1995; 121:98-102.

26. Carney JM, Sarke-Reed PE, Oliver CM. Reversal of age-related increase in brain protein oxidation, decrease in enzyme activity, and loss in temporal and spatial memory by chronic administration of the spintrapping compound n-tertibuthyl-a-phenylnitrone. Proc Natl Acad Sci. 1991;88:5633-7.
27. Fraga CG, Shigenaga MK, Helbock HJ. Ascorbic acid protects against endogenous oxidative DNA damage in human sperm. Proc Natl Acad Sci. 1991;24:1-4.

28. Street JC, Chadwick WR. Ascorbic acid requirements and metabolism in relation to organochloride pesticides. Ann NY Acad Sci. 1975;258:132-43.

29. Oliveira CP, Kassab P, Lopasso FP, Souza HP, Janiszewski M, Laurindo FR, Iriya K, Laudanna AA. Protective effect of ascorbic acid in experimental gastric cancer: reduction of oxidative stress. World J Gastroenterol. 2003;9(3):446-8.

30. Sasazuki S, Sasaki S, Tsubono Y, Okubo S, Hayashi M, Kakizoe T, Tsugane S. The effect of 5-year vitamin $\mathrm{C}$ supplementation on serum pepsinogen level and Helicobacter pylori infection. Cancer Sci. 2003;94(4):378-82

31. Telang S, Clem AL, Eaton JW, Chesney J. Depletion of ascorbic acid restricts angiogenesis and retards tumor growth in a mouse model. Neoplasia. 2007;9(1):47-56.

Conflict of interest: none Financial source: $\mathrm{CNPq}$

\section{Correspondence:}

Nelson Adami Andreollo

Rua Francisco Humberto Zuppi, 1234

13083-350 Campinas - SP Brazil

nandreollo@hotmail.com

Received: December 10, 2008

Review: February 12, 2009

Accepted: March 11, 2009

\section{How to cite this article}

Ramos AC, Araujo MR, Lopes LR, Andreollo NA. Role of the vitamin C in diethylnitrosamine-induced esophageal cancer in Wistar rats. Acta Cir Bras. [serial on the Internet] 2009 May-Jun;24(3). Available from URL: http://www.scielo.br/acb

*Color figures available from www.scielo.br/acb 